\title{
PRAVNO-POVIJESNI PRIKAZ RAZVOJA REGULACIJE INSTITUTA IZMOLJENE POSUDBE U HRVATSKOM PRAVU
}

\author{
Doc. dr. sc. Jelena Kasap* \\ Doc. dr. sc. Višnja Lachner**
}

\author{
UDK: 347.472 \\ https://doi.org/10.30925/zpfsr.41.2.7 \\ Ur.: 7. veljače 2020 . \\ Pr.: 1. srpnja 2020. \\ Pregledni rad
}

\section{Sažetak}

Nerijetko se u svakodnevnom govoru, čak $i$ u pravnom kontekstu stavlja znak jednakosti između dvaju obvezno pravnih instituta izmoljene posudbe, tj. prekarija $i$ posudbe te se naglašava opozivost kao jedina okolnost njihova razgraničenja. Uvažavajući mišljenje pravnih teoretičara prema kojem se pravni učinak izmoljene posudbe može ostvariti primjenom pravila o posudbi, neke od modernih kodifikacija građanskog prava propustile su normirati izmoljenu posudbu kao samostalan pravni institut. Ipak, hrvatski je zakonodavac, vodeći se povijesnom primjenom austrijskog Općeg građanskog zakonika na hrvatskom području normirao institut izmoljene posudbe zasebnom zakonskom odredbom i time ga definirao podvrstom ugovora o posudbi. Vrlo rijetka uporaba ovog instituta u pravnoj praksi, kao i izostanak interesa za pravnu narav izmoljene posudbe u modernoj teoriji građanskog prava, čine prirodu ovog instituta i dalje nedostatno jasnom. Komparativnom analizom pravne teorije, ali $i$ stranoga zakonodavstva koje je poslužilo kao podloga izradi zakonskog okvira posudbe u hrvatskom pravu nastojat će se utvrditi osobitosti izmoljene posudbe te ukazati na slučajeve u kojima je primjena ovog instituta, osobito oportuna. Unatoč sličnosti dvaju spomenutih pravnih poslova posudbe i izmoljene posudbe na koju će se ukazati u radu, temeljna je svrha ovog istraživanja naglasiti važnost svakoga instituta uzimajući u obzir osobitosti koje ih razgraničavaju te potvrđuju kako oba instituta imaju svoju zasebnu svrhu, praktičnu važnost $i$ iskustvo postojanja u hrvatskom pravu.

Ključne riječi: prekarij; izmoljena posudba; posudba; opozivost; Opći građanski zakonik.

* Dr. sc. Jelena Kasap, docentica, Pravni fakultet Sveučilišta Josipa Jurja Strossmayera u Osijeku; jkasap@pravos.hr.

** Dr. sc. Višnja Lachner, docentica, Pravni fakultet Sveučilišta Josipa Jurja Strossmayera u Osijeku; vlachner@pravos.hr. 


\section{REGULACIJA INSTITUTA IZMOLJENE POSUDBE U SREDNJOVJEKOVNIM IZVORIMA HRVATSKOG PRAVA}

Razumjeti pravnu prirodu, ali i potrebu za zakonskim normiranjem instituta izmoljene posudbe, poznatijeg kao prekarij (lat. precarium) u sustavima koji pripadaju zapadnoeuropskom pravnom krugu zahtijeva sustavnu raščlambu normativnog, ali i povijesno-pravnog konteksta koji je prethodio donošenju Zakona o obveznim odnosima 2005., kojim je izmoljena posudba uvrštena u katalog obvezno-pravnih ugovora.

Kada je riječ o hrvatskom srednjovjekovnom pravu kao i kod ostalih pravnih instituta, pravnoj analizi izmoljene posudbe mora se pristupiti uz uvažavanje partikularizma te uglavnom neujednačenih izvora koji su relevantni za ovu problematiku. Već uvidom u dostupnu literaturu i izvore može se primijetiti da se institut izmoljene posudbe neobično rijetko spominje u dostupnim pravnim tekstovima koji veliku pozornost posvećuju nekim u praksi učestalijim pravnim odnosima.

Kako hrvatski teritorij tijekom kasnoga srednjeg vijeka nije bio jedinstveni pravni sustav pravni će se izvori u ovom istraživanju dijeliti na one koji su vrijedili na teritoriju srednjovjekovnih priobalnih gradova i otoka, tj. područje Istre i Dalmacije te one koji su vrijedili na teritoriju kontinentalne Hrvatske, a koji se u povijesno pravnoj literaturi odnose na srednjovjekovno područje Slavonije. ${ }^{1}$ Pravni izvori prve skupine, koji su vrijedili na području srednjovjekovne Istre i Dalmacije u svojem sadržaju sporadično normiraju institut posudbe. Besplatnost posudbe u svim je izvorima koji se referiraju na spomenuti institut, temeljno obilježje toga pravnog odnosa, a određenost načina i vremena uporabe posuđene stvari nije, barem kada je riječ o pisanim izvorima, upućivala na razlikovanje posudbe i izmoljene posudbe stvari. ${ }^{2}$ Institutu izmoljene posudbe kao samostalnom pravnom odnosu nije posvećena pozornost u sadržaju spomenutih izvora. Zbog toga polazimo od pretpostavke kako je činjenično stanje koje čini obilježje tog pravnog odnosa vrlo vjerojatno bilo subsumirano običnom posudbom. Kako je prekarij čest u primjeni u odnosima između bliskih pojedinca vjerojatno je bio uređen normama običajnog prava te je nedostatno često rezultirao sporovima u kojima je regulacija toga posla vjerojatno bila uvrštena u sadržaj tada

1 Ivan Beuc, Povijest država i prava na području SFRJ (Zagreb: Narodne novine, 1989.), 19 i 208.

2 Posudba je u spomenutim srednjovjekovnim izvorima, tj. u statutima koji ju spominju besplatni, realni ugovor kojim se predaju na uporabu nepotrošne stvari s obvezom njihova vraćanja po završetku uporabe. Definiciju pravnog odnosa pronalazimo u Statutu grada Splita, III. knj., gl. 75. koja nosi naslov „O posudbi i ostavi“ te u IV. knj., gl 119. Statut grada Splita, srednjovjekovno pravo Splita, 2. Izdanje, (Split: Književni krug, 1987). Nadalje, u III. knj., gl. 4. Paškoga statuta. Dalibor Čepulo, Statut Paške općine. Statuta Communitatis Pagi (Pag, Zagreb: Ogranak Matice Hrvatske u Pagu - Pravni fakultet Sveučilišta u Zagrebu, 2011.). U III. knj., gl. 4. Rapskog statuta, Lujo Margetić i Petar Strčić, Statut rapske komune iz 14. stoljeća = [Statut communis Arbae] (Rab-Rijeka: Adamić, 2004.). U čl. 49a Poljičkog statuta, M. Pera, Poljički statut (Split: književni krug Split, 1988.), Zajam i posudba predmet su zajedničke regulacije Krčkog statuta pod naslovom De mutuo vel commodato, I., 43, 5. Lujo Margetić, Krčki (Vrbanski) statut iz 1388. (Krk: Povijesno društvo Saveza povijesnih društava Hrvatske, 1988.). 
relevantnih pravnih izvora.

Regulaciju instituta posudbe i izmoljene posudbe na slavonskom području nastojalo se interpretirati na temelju odredaba ugarskoga prava. Na istim je osnovama utemeljen i Iločki statut, jedini dostupni izvor koji je na spomenutom području regulirao posudbu. Izmoljena posudba, kao poseban pravni odnos, nije uvrštena $u$ katalog normiranih obveznih ugovora. Zanimljivo, posudba nije uređena ni odredbama Tripartitnog prava. ${ }^{3}$ Premda spomenuta okolnost s jedne strane iznenađuje s obzirom na to da se tripartitnim pravom nastojalo urediti pravne odnose prisutne u praktičnoj uporabi na hrvatsko-ugarskom području, s druge ne ostavlja mjesta sumnji kako je riječ o prijateljskom odnosu, vjerojatno učestalom u socijalnoj zbilji za kojeg nije postojala osobita potreba za pravnom regulacijom. Navedeni pravni odnos, naime, nije često rezultirao sporovima koji bi zahtijevali intervenciju sudova.

U pokušaju popunjavanja praznine u regulaciji ovog instituta i uvažavajući činjenicu da se srednjovjekovno slavensko obvezno pravo iz razdoblja nakon stupanja na snagu Verbecijevog Tripartita 1514. ne može prikazati bez osvrta na tada važeće hrvatsko-ugarsko pravo, u nastavku istraživanja učinjen je kratak osvrt na Institutiones iuris Hungarici, autora Kelemena iz 1818. koje su bez sumnje važan pravni izvor za tumačenje onih pravnih ustanova koje nisu regulirane tripartitnim pravom. ${ }^{4}$

Ugarsko privatno pravo rijedak je izvor srednjovjekovnog prava koji spominje izmoljenu posudbu u svojem sadržaju te ju definira po uzoru na odredbe rimskog prava. Prema odredbama ugarskog prava primarno je regulirana posudba kao nominatni, besplatni, realni ugovor kojim se nepotrošne stvari predaju drugome besplatno i na određeno vrijeme, a on ih je po isteku vremena dužan vratiti (lat. in specie, et statu quo). U nastavku odredbe i različito od ugovora o posudbi te uz uvjet da pravnim poslom nisu ugovoreni vrijeme ni uporaba stvari, a stvar je predana na uporabu posudovniku, definira se prekarij, tj. izmoljena posudba (Certum debere esse tempus et usum, secus precarium sapiet).

U sadržaju spomenutog izvora izmoljena posudba stvari pravni je odnos kojem trajanje ovisi o volji posuditelja. No, kao što to ističe von Jung ispunjenjem prethodno spomenutih pretpostavki ne nastaje ugovor o posudbi, već pravno obvezujući prekarij. ${ }^{5}$ Proizlazi, naime kako izmoljena posudba, tj. prekarij uopće nije pravi ugovor. Unatoč tome što nismo uspjeli pronaći izravnu pravnu odredbu u drugim izvorima hrvatskougarskog prava ovu tvrdnju smatramo relevantnom zato što joj je posebna pozornost posvećena u pravnoj teoriji koja se bavila tumačenjem sadržajno istovjetne odredbe Općeg građanskog zakonika, a koja je posebno raščlanjena u nastavku.

3 Mihajlo Lanović, Privatno pravo Tripartita (Zagreb: Tisak „Tipografija“, 1929.).

4 Posudba je prema odredbama ugarskoga prava definirana u glavi XXIX., § 294. na sljedeći način: Contractus nominatus, beneficus, realis, quo res non fungibilis ad certum usum, et tempus, alteri gratis, et ea lege traditur, ut eadem in specie, et statu quo, restituatur. Imre Kelemen, Institutiones iuris Hungarici 2. (Budae: Budae Univ. Hungaricae, 1818.), 565. Iločki statut neizravno je regulirao institut posudbe u V. knj., gl. 26. Statut grada Iloka, (Vinkovci: Separat iz godišnjaka MH Vinkovci, 1970.).

5 Johann von Jung, Darstellung des Ungarischen Privat-Rechtes. Nach dem Werke: Institutiones Juris privati Hungarici, Emerich von Kelemen, Bd. 2., 2. Aufl. (Wien: Beck, 1827.), 9. 


\section{REGULACIJA INSTITUTA IZMOLJENE POSUDBE PRIJE STUPANJA NA SNAGU ZAKONA O OBVEZNIM ODNOSIMA IZ 2005.}

U pojedinim dijelovima Hrvatske kao sastavnog dijela Habsburške Monarhije Opći građanski zakonik (tj. austrijski Allgemeines Bürgerliches Gesetzbuch/ABGB, dalje: OGZ), ${ }^{6}$ stupio je na snagu već 1812 ., a 1853, 1. svibnja na temelju carskog patenta od 29. studenog 1852. počeo je vrijediti na čitavom njezinom teritoriju, tj. na području Kraljevine Ugarske, Hrvatske i Slavonije. ${ }^{7}$ Uvođenje OGZ-a na područje Hrvatske imalo je znatne reperkusije na uspostavu veze hrvatskoga pravnog poretka sa suvremenim kontinentalno europskim pravnim krugom (rimsko-germanske pravne obitelji). Uspostava OGZ-a u Hrvatskoj rezultirala je ukidanjem dotadašnjega domovinskog, tj. hrvatsko-ugarskog prava koje je do tada važilo kao posebno pravo te onemogućilo primjenu općeg prava, čak i kao supsidijarnoga pravnog izvora. ${ }^{8}$ Zbog toga su, kada je riječ o institutu izmoljene posudbe odredbe OGZ-a koje se

6 OGZ je proglašen carskim patentom 1811. u austrijskim nasljednim zemljama Habsburške Monarhije. Bio je izrađen po uzoru na pandektno pravo, kanonsko, feudalno i njemačko običajno pravo. Peter Stein, Rimsko pravo i Europa - Povijest jedne pravne kulture, (Zagreb: Golden marketing - Tehnička knjiga, 2007.), 126; Mihajlo Vuković, Opći građanski zakonik- $s$ novelama i ostalim naknadnim propisima (Zagreb: Školska knjiga, 1955.), V.-VII. O postupku donošenja zakonika vidi više: Peter A. J. van den Berg, The Politics of European Codification (Groningen, Amsterdam: Europa Law Publishing, 2007.), 85-119. Ivan Beuc, Povijest država $i$ prava na području SFRJ (Zagreb: Narodne novine, 1989.), 19 i 208.

7 Mirjana Gross, Počeci moderne Hrvatske (Zagreb: Globus, Centar za povijesne znanosti Sveučilišta u Zagrebu 1985.), 109; Nikola Gavella et al., Hrvatsko građanskopravno uređenje i kontinentalnoeuropski pravni krug (Zagreb: Pravni fakultet u Zagrebu, 1994.), 11. O utjecaju odredaba OGZ-a na hrvatsku pravnu tradiciju vidjeti: Marko Petrak, „Rimska pravna tradicija i hrvatsko stvarno pravo“, Zbornik Pravnog fakulteta u Zagrebu 52, br. 2 (2002): 1047-1050.

8 U hrvatskim krajevima prije stupanja na snagu OGZ-a nije postojao jedinstveni sustav pravnih pravila kojim su se uređivali obveznopravni odnosi. Slučajevi regulacije instituta posudbe bili su iznimno rijetki. U Ugarskoj, kao i u Slavoniji, nije došlo do recepcije rimskog prava u onom opsegu koliko u Njemačkoj i Francuskoj, no kada je riječ o posudbi, ipak se može uočiti recepcija rimskih pravila. To je osobito izraženo u Institutiones iuris Hungarici, autora Kelemena iz 1818. Institut posudbe objekt je izravne regulacije ugarskog prava koje ga definira kao imenovani, realni ugovor kojim se besplatno prenose stvari posudovniku na određenu uporabu i određeno vrijeme, a koje je posudovnik obvezan vratiti in specie. Posudba je definirana u glavi XXIX., $\S 294$. na sljedeći način: Contractus nominatus, beneficus, realis, quo res non fungibilis ad certum usum, et tempus, alteri gratis, et ea lege traditur, ut eadem in specie, et statu quo, restituatur. Kelemen, Institutiones iuris Hungarici, 565. Putz ističe kako posudba nije bila regulirana pravnim aktima, već u teoriji, pri čemu se poziva na ranije citirani izvor Institutiones iuris Hungarici. Više o regulaciji posudbe u ugarskom pravu vidjeti: Putz, Karl, System des ungarischen Privatrechts, (Wien: Verlag der G.J. Manz'schen Buchhandlung, 1870.), 242-243. Isto se može uočiti u sadržaju statuta pojedinih hrvatskih gradova gdje je posudba regulirana pod snažnim utjecajem Justinijanovih odredaba. Osobit je to slučaj u odredbama Krčkog statuta iz 1480. (I., 54 i III, 58). Vidi više o tome: Lujo Margetić, Srednjovjekovno hrvatsko pravo. Obvezno pravo (Zagreb, Rijeka: HAZU, 1997.), 104-105; Lujo Margetić, Ivan Beuc i Dalibor Čepulo, Hrvatska pravna povijest u europskom kontekstu (Zagreb: Pravni fakultet u Zagrebu, 2005.), 154; Lujo Margetić, Osnove obveznog prava na kvarnerskom području u srednjem vijeku (Zagreb: Jugoslavenska akademija znanosti i umjetnosti, 1989.), 105. 
analiziraju u nastavku relevantni pravni okvir koji je na snazi na području Hrvatske nakon stupanja na snagu OGZ-a.

Nakon raspada Austro-Ugarske Monarhije 1918. OGZ je zadržao pravu relevantnost na hrvatsko- slavonskom području. Južnoslavenska država nastala nakon Prvog svjetskog rata norme OGZ koristila je kao posredan ili neposredan pravni izvor. ${ }^{9}$ Premda je novonastalu državu obilježio pravni partikularizam, kojeg je obilježavala pravna primjena različitih šest pravnih područja, OGZ je primjenjivan na području Bosne i Hercegovine još od austrougarske okupacije 1878. Na srpskom području primjenu OGZ-a omogućio je Srbski građanski zakonik iz 1844., koji je zapravo bio skraćeni prijevod izvornoga teksta OGZ-a. OGZ nije primjenjivan na području Crne Gore jer je ondje vrijedilo pravo Opšteg imovinskog zakonika iz 1888. Radi unifikacije građanskog prava 1934. izrađena je Predosnova građanskog zakonika za Kraljevinu Jugoslaviju utemeljena na odredbama OGZ-a, ${ }^{10}$ dok su odredbe koje su odstupale od izvornog teksta imale biti shvaćene kao modernija i naprednija inačica zakonskoga teksta. ${ }^{11}$ Tekst Predosnove u $\S 21$. definirao je i ugovor o posluzi (posudi). ${ }^{12}$ Kako je kao uzor autorima teksta Predosnove poslužio OGZ ne iznenađuje kako je regulacije prekarija također preuzeta iz istog izvora. ${ }^{13}$

Prestankom Kraljevine Jugoslavije obustavljen je rad na izdavanju Predosnove. Premda, smatra Maurović, da je Predosnova i donesena i stupila na snagu ona ne bi mogla vrijediti na području Banovine Hrvatske jer je Banovina imala samostalnu nadležnost u pogledu građanskopravnoga zakonodavstva, osim na području obveznopravnih odnosa, gdje je zadržana zajednička nadležnost. ${ }^{14}$ OGZ i dalje je nastavio vrijediti.

Proglašenje Nezavisne Države Hrvatske (NDH) 1941. uvelike se odrazilo na primjenu OGZ-a. Kako je područje NDH tijekom ratnog razdoblja podijeljeno na dva dijela, područje pod vlašću ustanika (partizana) nije prihvaćalo važenje OGZ, naprotiv,

9 Da je posudba bila regulirana prema OGZ-u jasno proizlazi iz sadržaja sljedećeg izvora: Privatno pravo u Vojvodini i Medjimurju (mađarsko privatno pravo) usporedjeno sa sistemom austr. O.g.z. s Originala Slovačko privatno pravo od Dr. Josipa Singera, preveo, preradio i dopunio Milan Svoboda (Zagreb: Tiskom Jugoslavenskog Novinskog (Ivan Malinar), 1926.), 109-110.

10 Ivan Maurović, Izvjesťaj o predosnovi gradjanskog zakonika za kraljevinu Jugoslaviju (Zagreb: T. Knjižare St. Kugli, 1934.), 5. Visoki stupanj podudarnosti iskazivao se u jeziku i stilu, sadržaju i razdiobu na paragrafe. U Predosnovi su neki tekstovi izostavljeni kao suvišni pa je ona umjesto 1502 paragrafa, koliko broji izvorni OGZ imala samo 1432 paragrafa. Gavella et al., Hrvatsko građanskopravno uređenje i kontinentalnoeuropski pravni krug, 25.

11 Vesna Radovčić, Pokušaj kodifikacije građanskog prava u Staroj Jugoslaviji: predosnova Građanskog zakonika za Kraljevinu Jugoslaviju (Zagreb: Institut za hrvatsku povijest, 1975.), 249-307.

12 Tekst $\S 960$. Predosnove koji definira ugovor o posudbi preuzeti je § 971. OGZ-a. Bertold Eisner, Mladen Pliverić, Mišljenja o Predosnovi građanskog zakonika za Kraljevinu Jugoslaviju (Zagreb: Pravničko društvo u Zagrebu, 1937.), 467.

$13 \S 963$. Predosnove definira prekarij na sljedeći način: Ako nije određeno ni vreme trajanja ni namera upotrebe, davalac stvari na poslugu može datu stvar natrag tražiti, kadgod mu se svidi.

14 Ivan Maurović, Nastojanja i Pokušaji da se reformira Opći građanski zakonik, Kratak pregled s nekoliko kritičkih napomena (Zagreb: Jugoslavenska akademija, 1940.), 97. 
nastojalo je prekinuti bilo kakav kontinuitet s predratnim pravnim sustavom. $\cdot{ }^{15} \mathrm{~S}$ druge strane, sudovi NDH primjenjivali su odredbe OGZ uz uvjet da nisu bile derogirane novim propisima. ${ }^{16}$ Radi uspostave jedinstvene primjene pravnih propisa na području građanskog prava vlast je NDH nastojala unificirati to pravno područje. Već 1943. donesena je Osnova građanskog zakonika za NDH koja je utemeljena na materijalu nastalom pri izradi Predosnove koja je utemeljena na OGZ. Time je OGZ ponovno trebao postati relevantnim izvorom građanskog prava u NDH. Kako Osnova nikada nije stupila na snagu, OGZ se i dalje koristio na području regulacije građanskopravnih odnosa. Takva je situacija uspostavljena do 1946. kada je snagu stupio Zakon nevaženju pravnih propisa donesenih prije 6. travnja 1941. Tim je pravnim propisom omogućena primjena isključivo pojedinih odredaba OGZ-a uz uvjet ispunjavanja određenih pretpostavki. ${ }^{17}$ Pretpostavke su nalagale sljedeće: da područje primjene pravila OGZ-a nije uređeno propisima nove države te da pravilo nije u suprotnosti s ustavnim odredbama nove države i njezinih sastavnica, niti u suprotnosti s načelima socijalističkoga pravnog poretka kao temeljne političke odrednice nove države. ${ }^{18}$ Donošenjem novih propisa, dakako, smanjivalo se područje primjene OGZ-a.

Stupanjem na snagu Zakona o obveznim odnosima (ZOO) iz 1978. ugovor o posudbi ponovno je uređen propisima OGZ-a, budući da novi zakon nije sadržavao posebne odredbe koje bi zasebno regulirale navedeni pravni posao. Iako je Skica za Zakon o obligacijama i ugovorima ${ }^{19}$ te odredbe sadržavala, zakon ih je propustio regulirati jer ugovor o posudbi nije bio tipičan instrument prometa roba i usluga, a Federacija je prema Ustavu SFRJ iz 1974. imala ovlast reguliranja samo robnih odnosa. ${ }^{20}$ Republička zakonodavstva, uključujući hrvatsko, nisu koristila ovlast, tj. ustavne mogućnosti za donošenje pravnih propisa na ovom području. Dosljedno se, stoga i nakon stupanja na snagu ZOO-a iz 1978. na regulaciju ugovora o posudbi, primjenjivao austrijski OGZ. Stoga će se u nastavku istraživanja vrlo detaljno raščlaniti regulacija toga instituta u austrijskom pravu.

15 Ivan Beuc, Povijest država i prava na području SFRJ, 202-203. O nastojanju kodifikacije hrvatskoga građanskog prava vidjeti: Gavella et al., Hrvatsko građanskopravno uređenje $i$ kontinentalnoeuropski pravni krug, 31- 34.

16 Gavella et al., Hrvatsko građanskopravno uređenje i kontinentalnoeuropski pravni krug, 31-34.

17 Derenčin, Osnova novoga kaznenoga zakona o zločinstvih i prestupcih za kraljevine Hrvatsku $i$ Slavoniju, 1879., 16; Maurović, Nastojanja i Pokušaji da se reformira Opći građanski zakonik, Kratak pregled s nekoliko kritičkih napomena, 84-97; Gavella et al., Hrvatsko građanskopravno uređenje i kontinentalnoeuropski pravni krug, 7-34.

18 Više o tome vidi: Radovčić, Pokušaj kodifikacije građanskog prava u Staroj Jugoslaviji: predosnova Građanskog zakonika za Kraljevinu Jugoslaviju, 249-307.

19 Konstantinović, Mihailo, Obligacije i ugovori: Skica za zakonik o obligacijama i ugovorima (Beograd, Izdanje Centra za dokumentaciju i publikacije Pravnog fakulteta, 1969.), 53; Skica za zakonik o obligacijama i ugovorima koju je izradio Mihailo Konstantinović, profesor Pravnog fakulteta u Beogradu je poslužila kao osnov za donošenje Zakona o obligacionim odnosima (1978), i više od toga. Zakon o obligacionim odnosima je u najvećem delu jednostavno reprodukovao odredbe Skice. Tamo gdje je odstupio, uglavnom je pogrešio. Slobodan Perović, „Stručno mišljenje o Nacrtu Zakona o obligacionim odnosima Republike Srpske/Federacije BiH (knj. I., Opšti deo, sa stanjem 28. I. 2003.)“, Anali Pravnog fakulteta u Beogradu, vol. 51, br. 1-2, (2003): 12.

20 Slobodan Perović, Obligaciono pravo, knjiga 1. (Beograd: Službeni List SFRJ, 1986.), 695. 


\section{PRAVNA REGULACIJA IZMOLJENE POSUDBE U ODREDBAMA ABGB-A}

\subsection{O pravnoj naravi instituta Bittleihe}

Izmoljena posudba, prekarij ili Bittleihe u tekstu ABGB-a definirana je u dijelu koji se odnosi na ugovor o posudbi (§ 971.- § 982.). Posudba je zaseban ugovorni odnos, a definicija odnosa sadržaj je paragrafa 971 . ABGB $-a .{ }^{21}$ Obilježja instituta posudbe predmet su zasebnog istraživanja pa ćemo se na njih u nastavku osvrnuti samo onoliko da bi se mogla utvrditi pravna priroda instituta na koji se pobliže referiramo.

Austrijski je zakonodavac definirao izmoljenu posudbu, tj. prekarij u § 974. ABGB-a. ${ }^{22}$ Sukladno sa sadržajem zakonskoga teksta izričito je navedeno kako prekarij nije pravi ugovor, već samo neobvezujuća izmoljena posudba (njem. ein unverbindliches Bittleihen (Precarium)). Na temelju pomalo neodređene zakonske kvalifikacije toga pravnog odnosa postavlja se pitanje je li prekarij u austrijskom pravu uopće ugovorni odnos?

Premda je zakonodavac isključio kvalificirati prekarij ugovornim odnosom na navedeno pitanje valja odgovoriti potvrdno. ${ }^{23}$ Slijedom brojnih tumačenja, koja su novijeg datuma, $\mathrm{u}$ austrijskoj pravnoj teoriji prekarij je ugovor, podvrsta ugovora o posudbi kod kojeg ugovorne stranke nisu obvezne ugovoriti vrijeme trajanje uporabe stvari niti svrhu, tj. način uporabe, već mogućnost opoziva uporabe stvari ovisi o volji posuditelja. ${ }^{24}$ Isto potvrđuje i pravna praksa na koju ćemo se u nastavku detaljnije osvrnuti.

Odbijanje ugovorne prirode prekarija rezultiralo bi višestrukim posljedicama na području vrednovanja odgovornosti prekariste. ${ }^{25}$ Ponajprije, obveza povrata stvari

$21 \S$ 971. ABGB: Wenn jemandem eine unverbrauchbare Sache bloß zum unentgeltlichen Gebrauche auf eine bestimmte Zeit übergeben wird; so entsteht ein Leihvertrag. Der Vertrag, wodurch man jemandem eine Sache zu leihen verspricht, ohne sie zu übergeben, ist zwar verbindlich, aber noch kein Leihvertrag.

22 § 974. ABGB: Hat man weder die Dauer, noch die Absicht des Gebrauches bestimmt; so entsteht kein wahrer Vertrag, sondern ein unverbindliches Bittleihen (Precarium), und der Verleiher kann die entlehnte Sache nach Willkühr zurückfordern.

23 Roman Reßler, Voraussetzungen der Unentgeltlichkeit bei prekaristischer Überlassung einer Wohnung für Wohnzwecke nach § 974 ABGB, pristup 30. rujna 2019., https://www.weka.at/ wohnrecht/News/Voraussetzungen-der-Unentgeltlichkeit-bei-prekaristischer-Ueberlassungeiner-Wohnung-fuer-Wohnzwecke-nach-974-ABGB?print=1. Kvalifikacija ovoga pravnog odnosa kao pravnog ugovora pronalazi se u starijoj literaturi. Primjerice, Swoboda u: Klang Heinrich Adalbert, Kommentar zum Allgemeinen Burgerlichen Gessetzbuch, Bd. 2., Halbd. 2. $\S \S 859$ bis 1089, Bearbeitet von Ernst Bettelheim, Franz Bschnitzer, Alfred Handl, Oskar Pisto, Wilhelm Schletzinger, Ernst Swoboda (Wien: Staatsdruckerei 1934.).

24 Andreas Riedler, Zivilrecht III, Schuldrecht, Besonderer Teil: Vertragliche Schuldverhaltnisse, 4. Aufl. (Wien: LexisNexis, 2015.), 116.

25 Josef Schey, Die Obligationsverhältnisse des österreichischen allgemeinen Privatrechts, $B d$. 1. (Wien: Manzsche k.u.k. Hof-Verlags- u. Universitäts-Buchhandlung., 1895.), 271; Horaz Krasnopolski, Osterreichisches Privatrecht, Bd. 3.: Österreichisches Obligationenrecht, Aus dessen Nachlaß hrsg. und bearb. von Bruno Kafka. Mit einem Geleitwort von Ludwig Mitteis, Mitarbeit: Mitteis, Ludwig; Herausgegeben von Kafka, Bruno (Berlin: Verlag: Duncker \& 
ne bi se mogla smatrati ugovornom obvezom te se ugovorne odredbe o odgovornosti ne bi mogle primijeniti na prekaristu. S tim u vezi, prekarist ne bi bio obvezan postupati obazrivo s predanom stvari kao što je to bio posudovnik u skladu s $\S 981$. ABGB-a. Na prekaristu bi se, prema tom tumačenju, trebale primijeniti odredbe ABGB-a o izvanugovornoj odgovornosti. Isto kao što prekarist ne bi imao obvezu obazrivog postupanja, ne bi mogao biti odgovoran ni za troškove redovite uporabe ili održavanja stvari iz $§ 981$. Naknadu učinjenih troškova ne bi mogao ostvariti kao pošteni posjednik, već samo u skladu s pravilima zakona o naknadi troškova koja se ima isplatiti nepoštenom posjedniku. Ostali učinci oduzimanja ugovorne prirode prekarija odrazili bi se već na području legitimacije za sklapanje ugovora, koja ne bi bila uvjetovana poslovnom sposobnošću ugovornih stranaka i time bi vjerojatno izazvala znatne poteškoće u ostalim stadijima njihova odnosa.

Nastojanja da se navedene negativne posljedice tumačenja pravne naravi prekarija izbjegnu prevladala su već u literaturi s početka 20. stoljeća. Klang smatra da je prekarij jednostrani pravni posao jer obvezuje prekaristu na povrat posuđene stvari. ${ }^{26}$ No, ne sumnja u njegovu ugovornu prirodu jer zakonska definicija prekarija ne navodi izričito da prekarij „nije ugovor“, već samo da nije „pravi ugovor“. Prema tome, nakon što se stranke sporazume o prepuštanju ili dopuštenju uporabe stvari njihovom suglasnom voljom ugovor nedvojbeno nastaje.

\subsection{Obilježja instituta Bittleihe}

Koje stvari mogu biti objektom ove specifične posudbe? Premda zakonska odredba objekte ne navodi izrijekom nema sumnje da, kako stoji u austrijskoj pravnoj teoriji, objektom prekarija mogu biti sve one stvari koje se mogu i posuditi. To su uglavnom pokretne i nepokretne stvari, no nije isključeno kako objektom prekarija mogu biti i prava, primjerice pravo zahvaćati i crpiti vodu iz izvora. ${ }^{27}$

Osobitosti prekarija koje proizlaze iz § 974. su besplatnost te opozivost koja ovisi o volji posuditelja. Besplatnost je nužni sastojak prekarija. Ona proizlazi iz prirode ovoga pravnog posla, okolnošću da je prekarij podvrsta ugovora o posudbi. Pogrešno je zaključiti, međutim, da ugovaranje naknade kod zaključenja ovoga pravnog posla dovodi do njegove ništetnosti. U austrijskoj su sudskoj praksi česti slučajevi ugovaranja naknade koja ne prelazi vrijednost redovite uporabe objekta koji se posuđuje. Dopušteno je, primjerice, ugovoriti plaćanje troškova redovite uporabe stvari tijekom trajanja prekarija. Tako ako je predmet posudbe vrt, strankama je dopušteno ugovoriti i troškove vodne naknade, ali porez kojim je nekretnina opterećena ima snositi posudovnik. ${ }^{28}$ Navedeni iznosi ne predstavljaju naknadu za

Humblot, 2013.), 271.

26 Klang, Kommentar zum Allgemeinen Burgerlichen Gessetzbuch, Bd. 2., Halbd. 2., \$§ 859 bis $1089 \S 974,701$.

27 Michael Schwimann, ABGB-Praxiskommentar, Bd. 4., $\$ \S 859-1089$ ABGB, 3. neue bearbeitete Aufl. (Wien: LexisNexis, 2006.), § 974, 4.

28 Petar Rummel, Komentar zum Allgeimenen buerglichen Gesetzbuch 1 § 1 bis 1089 ABGB (Wien: Manz Verlag 1983.), 1189. Sudska praksa: Mietslg 27.126; pristup 24. listopada, 2019., https://www.uibk.ac.at/zivilrecht/buch/kap3_0.xml\#Bittleihe\%20/Prekarium, 
uporabu stvari, već troškove njezina redovitog održavanja ili uporabe koje je prema $\S$ 981. obvezan snositi posudovnik.

Nejasno je, nadalje, moraju li stranke ugovoriti i mogućnost opoziva u bilo koje vrijeme koje ovisi o volji posuditelja kako bi navedena okolnost zaista i bila pravno relevantna. Prema vladajućem mišljenju u novijoj pravnoj teoriji čini se kako navedena okolnost može proizlaziti i iz okolnosti slučaja, čime opozivost prekarija u bilo kojem trenutku ne bi bila i nužni sastojak toga pravnog posla. ${ }^{29}$

Kako austrijska sudska praksa poznaje veliki broj slučajeva besplatnog (prekarijskog) prepuštanja stana radi stanovanja na koje se primjenjuje odredba $§ 974$. ABGB-a, nastao je problem kada je riječ o razlikovanju u nekom navedenom slučaju prepuštanja o prekariju ili, pak, najmu stana. ${ }^{30} \mathrm{Na}$ prvi je pogled razlika očigledna. Kod ugovora o najmu najmoprimac se obvezuje platiti naknadu kao ekvivalent uporabi stvari, dok kod prekarija to nije slučaj. Prema Ressleru, kako se na ugovor o najmu primjenjuju u cijelosti ili djelomično odredbe ABGB-a ili posebne odredbe Zakona o najmu MRG-a (njem. Mietrechtsgesetz ${ }^{31}$ ) najmodavac je obvezan predati stan na uporabu dok kod prekarija ne postoji pravni zahtjev kojim bi se posuditelja obvezalo na predaju stvari. ${ }^{32}$ Nužno je posebno voditi računa o naknadi koja je kod ugovora o najmu nužni sastojak pravog posla dok kod prekarija, kao što smo to ranije naveli, nije dopušteno ugovoriti naknadu za uporabu stvari, osim ako se pod naknadom ne podrazumijevaju redoviti troškovi održavanja stvari. S tim u vezi, važno je odrediti i koji su to troškovi. U odluci austrijskoga Vrhovnog suda stoji da su to oni troškovi povezani s uporabom stvari koji nisu suprotni odredbama zakona o prekariju. ${ }^{33} \mathrm{U}$ tom bi se slučaju radilo o troškovima tekuće uporabe stvari. ${ }^{34}$ Kako bi se spriječilo zaključivanje ugovora o najmu onda kada stranke namjeravaju zaključiti besplatni pravni posao, tj. prepustiti stan na besplatnu uporabu posudovniku, u praksi je ustaljeno koristiti određena pravila. Između ostalog, zaključiti prekarij u pisanom obliku koji inače nije pretpostavka valjanosti ovog pravnog posla. Nadalje, nužno je ugovoriti

29 Iz bogate austrijske sudske prakse vidjeti, LGZ Gratz, 3 R 72/86 Miet 38.085), A. Riedler, 116., Schwimann, ABGB-Praxiskommentar, Bd. 4., $\$ \S 859-1089$ ABGB $\S 974$, 3. neue bearbeitete Aufl., 5-7.

30 Primjer naveden iz sudske prakse kao i precizno navođenje razgraničenja posudbe i ugovora o najmu vidjeti u Petar Garai, Riss, „Zur Abgrenzung von Leihe und Miete (Anerkennungszings)“, Wohnrechtliche Blätter 22, 4 (2009): 129-132.

31 Bundesgesetz vom 12. November 1981 über das Mietrecht (Mietrechtsgesetz - MRG) StF: BGB1. Nr. 520/1981 (NR: GP XV RV 425 AB 880 S. 90. BR: S. 415.), pristup 21. listopada 2019., https://www.jusline.at/gesetz/mrg.

32 Roman Reßler, Voraussetzungen der Unentgeltlichkeit bei prekaristischer Überlassung einer Wohnung für Wohnzwecke nach § 974 ABGB, pristup 30. rujna 2019., https://www.weka.at/ wohnrecht/News/Voraussetzungen-der-Unentgeltlichkeit-bei-prekaristischer-Ueberlassungeiner-Wohnung-fuer-Wohnzwecke-nach-974-ABGB?print=1.

33 OGH vom 10.06.2015, 7 Ob 218/14f.

34 Takvi su troškovi komunalnih usluga koji uključuju troškove održavanja i kućne njege, operativne troškove dizala, troškove grijanja i tople vode. U tu kategoriju ne bi spadali doprinosi fonda za popravke nekretnine, djelomične otplate kredita za renoviranje, osiguranje imovine, bankovne naknade i poreze na imovinu. Kako navedeni troškovi druge vrste mogu biti karakterizirani kao naknada, na njih se ne mogu primjenjivati odredbe zakona o prekariju (10 Ob26/13s). 
opseg posudovnikovog prava besplatne uporabe stvari, ali i precizno ugovoriti koji se sve troškovi redovite uporabe stvari, tj. stana prenose na posudovnika. Korisno je definirati i modalitete godišnje naplate troškove uz obvezu da se prijeko plaćeni troškovi vraćaju posudovniku na kraju godine. ${ }^{35}$ Radi olakšanja postupka dokazivanja godišnji se izvještaju zadržavaju. Ipak, jednostavnija je mogućnost ugovoriti potpunu besplatnost uporabe stvari dane u prekarij kako bi se izbjegle komplikacije vezane za utvrđivanje pravne prirode navedenoga pravnog posla.

\subsection{Položaj prekarista u odredbama $A B G B-a$}

Jedno važno pitanje proizlazi iz nedostatno određene kvalifikacije ovoga pravnog odnosa. Kakav je pravni položaj prekariste te ima li prekarist pravo na pravnu zaštitu u odnosu na posuđenu stvar, ali i u kojem je obliku to pravo moguće ostvariti?

Različita su mišljenja u pravnoj literaturi kada je riječ o prekaristovu položaju u pogledu posjeda posuđene stvari, a ona uglavnom ovise o tome je li u konkretnom slučaju riječ o starijim ili pak novijim tumačenjima u sklopu pravne teorije. Dok su neki relevantni teoretičari građanskog prava s kraja 19. stoljeća, poput Scheya, ${ }^{36} \mathrm{o}$ ovome propustili odlučiti, drugi ${ }^{37}$ su bez sumnje utvrdili kako prekarist ima pravo na pravnu zaštitu u skladu s odredbama ABGB-a. Swoboda navodi kako se razlozi za tako različita tumačenja pravnog položaja prekariste mogu pronaći u različitoj interpretaciji pravne prirode prekarija kao i u razlikama u tumačenju $\S 345$. ABGBa. ${ }^{38}$ Premda je uzrok sporu u pravnoj literaturi prevladan, u onoj novijega datuma još uvijek nailazimo na različita tumačenja. Neki autori smatraju kako zbog mogućnosti da se prekarij opozove u bilo kojem trenutku na temelju volje posuditelja prekarist ne može biti u položaju posjednika prava. ${ }^{39}$ Različito od toga, Binder smatra kako u odnosu prema trećima prekarist jest posjednik prava u skladu s odredbama $§ 313$. tijekom trajanja pravnog odnosa. No, do izjave opoziva, posuditelj protiv prekariste ne može postupati posjedovnom tužbom. ${ }^{40}$

35 Roman Reßler, Voraussetzungen der Unentgeltlichkeit bei prekaristischer Überlassung einer Wohnung für Wohnzwecke nach § 974 ABGB, pristup 30. rujna 2019., https://www.weka.at/ wohnrecht/News/Voraussetzungen-der-Unentgeltlichkeit-bei-prekaristischer-Ueberlassungeiner-Wohnung-fuer-Wohnzwecke-nach-974-ABGB?print=1.

36 Schey, Die Obligationsverhältnisse des österreichischen allgemeinen Privatrechts., Bd. 1., 260.

37 Randa, Der Besitz nach österreichischem Rechte mit Berücksichtigung des gemeinen Rechtes, des preussischen, französischen und italienischen, des sächsischen und züricherischen Gesetzbuches, str. 676.

38 Klang, Kommentar zum Allgemeinen Burgerlichen Gessetzbuch, Bd. 2., Halbd. 2., $\$ \S$ 859 bis 1089, 702. Joseph Max von Winiwarter, Das persönliche Sachenrecht nach dem Oesterreichischen allgemeinen bürgerl. Gesetzbuche: Systematisch dargestellt und erläutert, 2. verm. und verb. Aufl. (Wien: Braumüller und Seidel, 1837.), 164, § 107. Kako je zakonodavac propustio definirati prekarij ugovornim odnosom ovakav je spor, kao što smo to ranije već objasnili, prevladan tek u recentnoj pravnoj praksi koja je prekarij nesporno potvrdila ugovornim odnosom.

39 Rudolf Wesler, Grundriss des burgerlichen Rechts, Bd. 2., Schuldrecht Allgemeiner Teil, 13. nubearbeitete Aufl., (Wien: Mansche Verlags und Universitatsbuchhandlung, 2007.), 203.

40 Schwimann, ABGB-Praxiskommentar, Bd. 4., §\$ 859-1089 ABGB § 974, 5-72006, § 974, 3637,870 . 
Prije raščlambe tumačenja vladajućih predstavnika važno je prisjetiti se da je u starijoj austrijskoj literaturi bilo zastupljeno mišljenje prema kojem je posudovnik $\mathrm{u}$ austrijskom pravu posredstvom stvari koju prima na uporabu Rechtsbesitzer, tj. posjednik prava uporabe stvari. Uz pretpostavku da se primjena istog pravnog položaja nastojala opravdati i u slučaju prekariste istražili smo ispravnost takvog shvaćanja primjenom odredaba o posjedu i posjedovnoj zaštiti ABGB-a. Odgovor na pitanje je li prekarist zaista posjednik prava te ima li s tim u vezi pravo na posjedovnu zaštitu u starijoj pravnoj znanosti nastajalo se pronaći tumačenjem § 345. ABGBa. ${ }^{41}$ Sadržaj navedenoga paragrafa određuje kada se posjed smatra nezakonitim i nepoštenim, tj. neistinitim, a iz definicije proizlazi zaključak o neistinitosti posjeda stečenog zlouporabom uslužnosti (lat. precario). Schey smatra da se obveznopravno dopuštenje prava uporabe može dati sve do opoziva koji ovisi o slobodnoj volji davatelja stvari, a time prekarist stječe pravni posjed i pravo na posjedovnu zaštitu. ${ }^{42}$ Klang je u komentaru ABGB-a prikladno objasnio da pravna narav prekarija ne ovisi o tome ima li prekarist pravo na posjedovnu zaštitu, već ovisi o interpretaciji $§ 345$. ABGB-a. ${ }^{43}$ Posjedovnu zaštitu, prema tome, može imati samo prekarist kojem je uporaba stvari odobrena na temelju sporazuma stranaka. Onaj tko stvar posjeduje zloupotrebom nema pravni temelj posjedovanja, a s tim u vezi, ni posjedovnu zaštitu. ${ }^{44}$

Vezano za posjedovnu zaštitu prekariste u novijoj austrijskoj pravnoj teoriji nije usvojeno jedinstveno mišljenje. Schwimann ističe da je u odnosu prema trećima prekarij institut koji omogućuje stjecanje posjeda u skladu s $\S 313 .{ }^{45}$ Time prekarist ostvaruje pravo na zaštitu protiv trećih osoba, ali ne i protiv davatelja stvari. ${ }^{46}$ Prekarist prema shvaćanju austrijskog zakonodavca nije posjednik stvari, već obični detentor, ${ }^{47}$ a time uživa posjedovnu zaštitu samo protiv trećih osoba, ne i protiv davatelja stvari. ${ }^{48}$ No, pronalaze se i drukčija tumačenja pravnog položaja prekarist. Primjerice, Koziol i Welser priznaju prekariju ugovorne učinke, no različito od prethodno spomenutih

$41 \S 345$. ABGB-a: Ako tko stječe posjed silom, ili potajno s lukavstvom ili molbom, i nastoji pretvoriti u stalno pravo ono što mu je dopušteno od jedne uslužnosti, bez obveze istu uslugu i dalje mu činiti; posjed po sebi nezakonit i nepošten postaje suviše neistinit; inače se smatra istinit.

42 Schey, Die Obligationsverhältnisse des österreichischen allgemeinen Privatrechts, Bd. 1, 271.

43 Klang, Kommentar zum Allgemeinen Burgerlichen Gessetzbuch, 2. Bd., 2. Halbd., $\$ 859$ bis 1089, §974, 702.

44 Apathy Riedler, Bürgerliches Recht, Bd. 3. Schuldrecht Besonderer Teil, 649.

45 Schwimann, ABGB-Praxiskommentar, Bd. 4., §§ 859-1089 ABGB § 974, 5-7§ 974, 863.

46 Opće prihvaćeno pravno mišljenje u austrijskom pravu daje prekaristu mogućnost korištenja sredstava protiv smetanja posjeda protiv trećih osoba. Time se negira ranije izraženo tumačenje položaja prekarista prema kojem prekarist nema pravo na posjedovnu zaštitu jer on nije posjednik prava. Apathy, Riedler, Bürgerliches Recht, Bd. III Schuldrecht Besonderer, 649.

47 Prema sadržaju $§ 318$. ABGB-a onaj tko drži stvar u tuđe ime nema još uvijek pravnog naslova da bi mogao uzeti stvar u posjed. ABGB time zakonski posjed definira i s negativne strane. Naime, detencija ili držanje stvari je stanje koje još uvijek ne daje pravi temelj za stjecanje posjeda.

48 Franz Gschnitzer, Sachenrecht (Berlin: Springer-Verlag Berlin Heidelberg, 1968.), 22; Barta smatra da obični imatelj stvari, koji nije pravni posjednik ima pravo na samopomoć i pravo samozaštite, ne i mogućnost korištenja posjedovne tužbe.; Heinz Barta, Zivilrecht: Grundriss und Einführung in das Rechtsdenken, 2, (Wien: WUV-Univ.-Verlag, 2004.), 154. 
izvora ne negiraju mogućnost ostvarivanja posjedovne zaštite prekarista protiv trećih osoba zato što prekarist prema ABGB-u nije posjednik prava. ${ }^{49}$ Prevladavajuće je stajalište da prekarist kao obični imatelj stvari ne stječe posjed, već detenciju nad posuđenom stvari. U skladu s time, prekarist nije posjednik stvari. ${ }^{50}$ No, ipak uživa posjedovnu zaštitu protiv trećih osoba. ${ }^{51}$ Kada bi prekarist posjedovnu zaštitu mogao ostvariti i protiv davatelja stvari, vjerujemo da bi nestala praktična potreba za ovim pravnim institutom s obzirom na to da bi u odnosu na povrat stvari dane u prekarij, davatelj stvari mogao postupati samo s petitornom tužbom, $\mathrm{tj}$. pozivati se na svoje pravo vlasništva.

Razmatranje o pravnoj naravi prekarija i pravnom položaju prekariste upućuje na sljedeće zaključke. Iz $§ 974$. ABGB-a proizlazi da „,prekarij“ nije „,stvaran ugovor“. Iz naslova ugovora ne proizlaze ni pravo ni obveza ni za davatelja ni za primatelja. Predaja stvari ne znači prijenos prava uporabe koje ,nastavlja trajati“ i nakon toga trenutka. Iz toga slijedi da u skladu s $\S 313$, prekarist putem te predaje ne stječe posjed prava. Njegova detencija se temelji, kao što to dodaje $\S 974$., samo na „,neobvezujućem prekariju“". Ako prekarist nakon izjavljenog opoziva protivno volji davatelja nastoji „ono što mu je dopušteno iz usluge, bez podvrgavanja trajnoj obvezi, pretvoriti u trajno pravo", tada prekarist samovoljno dolazi u posjed stvari ili prava uporabe. ${ }^{52}$ No, taj njegov je posjed neistinit prema $\S 345$. te mu po potrebi može biti oduzet tužbom za zaštitu posjeda iz $\S 346 .{ }^{53} \mathrm{U}$ skladu sa sadržajem paragarafa protiv svakoga neistinitog posjednika može se zahtijevati uspostava prijašnjeg stanja kao i obeštećenje. Čini se kako je jednostavnije ostvariti povrat stvari primjenom posjedovne zaštite. Kako je prekarij podvrsta ugovora o posudbi, prikladnost korištenja ugovorne tužbe protiv prekariste u austrijskom pravu (premda je takva tužba u starijoj literaturi višestruko odbijana zbog različitih tumačenja pravne naravi prekarija) nesporna je.

\section{PRAVNA REGULACIJA IZMOLJENE POSUDBE U ODREDBAMA ZOO-A IZ 2005.}

Osamostaljenjem Hrvatske 1991. zakonodavac je preuzeo jugoslavenske pravne propise te učinio samo najnužnije izmjene u pogledu pravnih normi radi prilagodbe novom političkom poretku. U službenom glasilu Narodne novine, br. 53/91., objavljena je odluka o prekidanju svih državnopolitičkih veza s bivšom državom te Zakon o preuzimanju Zakona o osnovnim vlasničkopravnim odnosima i Zakon o preuzimanju

49 Helmut Koziol, Rudolf, Wesler, Grundiss des Bürgerlichen Rechts, Bd. II., 13. Aufl. (Wien: MANZ Verlag Wien. 2007.), 203.

50 U nekim starijim tumačenjima pronalaze se i suprotna stajališta. Primjerice, Moriz von Stubenrauch, Commentar zum österreichischen Allgemeinen bürgerlichen Gesetzbuche, 8. Aufl. (Wien: Mansche Verlags und Universitatsbuchhandlung, 1903.), § 974., 175.

51 Daniela Wieger, Besitzstörung, Praxisleitfaden mit vielen Beispielen und Mustern (Wien: Linde Verlag Ges.m.b.H., 2016.), 3-4.

52 Wieger, Besitzstörung, Praxisleitfaden mit vielen Beispielen und Mustern, 3-4.

53 Winiwarter, Das persönliche Sachenrecht nach dem Oesterreichischen allgemeinen bürgerlichen, 164. 
Zakona o obveznim odnosima. ${ }^{54}$ Oba ta pravna propisa izravno su se pozivala na OGZ te su nametnuli primjenu pravila koja su sadržana u njemu. ${ }^{55}$ Time je primjena pravila OGZ-a koja se odnose na ugovor o posudbi ozakonjena te je imala pravnu snagu sve do 1. siječnja 2006. kada je na snagu stupio novi $Z{ }^{5} O^{56}$ koji je zasebno uredio institut posudbe u paragrafima od 509. do $518 .{ }^{57}$

Institut izmoljene posudbe kojeg ZOO naziva prekarij uređen je u čl. 515 . st. 3. ZOO-a. ${ }^{58}$ Isto kao i u OGZ-u prekarij je u hrvatskom pravu uređen sukladno odredbama koje se odnose na regulaciju ugovora o posudbi. Bez rasprave o klasičnom shvaćanju pravnog položaja prekariste prije stupanja na snagu ZOO-a iz 2005. prikazat će se pravni položaj prekariste u odnosu na novu zakonsku regulaciju. Kako je u Hrvatskoj do uređenja prekarija 2005. vrijedilo austrijsko pravo OGZ-a upućivanje na klasično učenje u pravnom položaju prekariste u austrijskom zakonu polazna je točka za razumijevanje regulacije istoimenog instituta u novom ZOO-u. No, i moderna koncepcija prekarija nije znatno odstupila od regulacije istoimenoga instituta u OGZ-u. Naime, prekarij je prema ZOO-u isto kao i prema OGZ-u podvrsta ugovora o posudbi, nikako zasebni pravni institut.

Ako nije dogovoreno trajanje niti svrha uporabe posuđene stvari tada nije riječ o zaključivanju ugovora o posudbi, već o prekariju. A jedna je od osnovnih osobina navedenog instituta njegova opozivost u bilo kojem trenutku. To znači da je pravnoj literaturi i sudskoj praksi zauzeto stajalište prema kojem je posudovnik prekarist obvezan vratiti posuđenu stvari u trenutku kada to posuditelj zatraži. Već na početku utvrđivanja važnih obilježja instituta prekarij mora se utvrditi je li u hrvatskom pravu prihvaćeno stajalište da svako zaključivanje ugovora o posudbi kojim nisu utvrđeni trajanje ili svrha uporabe posuđene stvari znači i zaključivanje prekarija, iako stranke nisu namjeravale zaključiti takav oblik posudbe. Posebno je to važno zbog pravnoga položaja posudovnika koji biva izložen negativnim posljedicama vraćanja posuđene stvari u trenutku u kojem to posuditelj zatraži čak i ako nije imao priliku upotrijebiti posuđenu stvar. U starijoj je literaturi koja se bavila utvrđivanjem pravnih obilježja ugovora o posudbi nastalih u skladu s pravilima OGZ-a utvrđeno da prekarij ne može biti zaključen kao zakonska pretpostavka u trenutku kada ugovorom nisu određeni trajanje i svrha uporabe posuđene stvari. Prema Đuroviću i Dragaševiću, navedeno presumiranje zaključivanja prekarija izazvalo bi pravnu nesigurnost sa stajališta posudovnika koji ne bi siguran ima li uopće pravo upotrebe ako bi posuditelj odmah po zaključivanju ugovora zahtijevao povrat stvari. ${ }^{59}$ Isto su mišljenje zastupali Perović

54 Zakon o preuzimanju zakona o obveznim odnosima, Narodne novine, br. 53/91.

55 Vilim Gorenc et al., Obvezno pravo, Posebni dio 1., Pojedini ugovori (Zagreb: Novi informator, 2012.), 118.

56 Zakon o obveznim odnosima, Narodne novine, br. 35/05., 41/08., 125/11., 78/15.

57 Vidi više: Ivica Crnić, Zakon o obveznim odnosima: opsežna sudska praksa, napomene $i$ komentari, detaljno abecedno kazalo pojmova, 6., izmijenjeno i dopunjeno izd. (Zagreb: Organizator, 2016.), 1013.

58 Čl. 515. st. 3. ZOO: „Ako nije ugovoreno niti trajanje niti svrha uporabe (izmoljena posudba), posudovnik je dužan vratiti posuđenu stvar čim to posuditelj zatraži““.

59 Radomir Đurović i Momir Dragašević, Obligaciono pravo: sa poslovima prometa (Beograd: Savremena administracija, 1980.), 256. 
i Loza. ${ }^{60}$ Zakonodavac je, nasuprot tome, u čl. 515. st. 3. vrlo izričito predvidio zaključivanje prekarijske posudbe u svakom slučaju posuđivanja stvari bez izričitog ugovaranja trajanja ili svrhe uporabe posuđene stvari. Zakonska odredba ne ostavlja prostor za drukčije tumačenje: „Ako nije ugovoreno niti trajanje niti svrha uporabe, posudovnik je obvezan vratiti posuđenu stvar čim to posuditelj zatraži““ ${ }^{61}$

Sljedeća obilježja karakteriziraju prekarij u hrvatskom pravu. Stvar se predaje na besplatnu uporabu, objekt prekarija je tuđa i nepotrošna, iznimno potrošna stvar, a vrijeme uporabe nije ugovorom određeno, već ovisi o volji davatelja stvari u prekarij. Navedena obilježja ne odstupaju od regulacije istog odnosa u § 974. OGZ-a. Kako su stajališta o prekariju kao „pravom ugovoru“ u suvremenom austrijskom pravu prevladana preostaje utvrditi o potpunom preuzimanju pravnih pravila kojima se regulira ovaj institut $u$ austrijskom pravu. Usprkos usvajanju zasebnog pravnog okvira neka pravna pitanja i dalje zahtijevaju da ih se pobliže utvrdi radi postizanja pravne sigurnosti. Primjerice, iako OGZ nije predvidio posudbu prava, austrijska je pravna teorija tumačenjem posudbe stvari iznjedrila interpretaciju mogućnosti posudbe prava posredstvom posudbe stvari. U odredbama ZOO-a i ZV-a takva mogućnost nije primjerena prometu pravima, a čak je izraz posudbe prava proturječan hrvatskom stvarno-pravnom uređenju. Smatramo da je zakonodavac dosta jasno ograničio objekt posudbe na potrošne i nepotrošne stvari u čl. 510. ZOO-a, a šutnju koja je u pravnoj teoriji o tom pitanju prisutna tijekom duljeg razdoblja trebalo bi prekinuti analizom stvarno-pravnog uređenja i regulacije posebnih propisa na materijalno-pravnoj razini.

Prekarist je isto kao i posudovnik u hrvatskom pravu neposredni posjednik posuđene stvari. Takvo tumačenje pravnog položaja prekariste može se pronaći već u pravnoj literaturi nastaloj prije no što je prekarij definiran u ZOO-u. ${ }^{62}$ Njegov je pravni položaj reguliran u skladu sa stvarno- pravnim odredbama u Zakonu o vlasništvu i drugim stvarnim pravima. ${ }^{63}$ Sukladno s odredbom čl. 10. st. 3. ZV-a posudovnik, tj. prekarist neposredni je posjednik posuđene stvari budući da je ovlašten na temelju obvezno-pravnog odnosa posjedovati stvar. ${ }^{64}$ Njegov je posjed u skladu sa ZV-om zakonit, istinit i pošten. ${ }^{65}$ Pravni položaj prekariste u hrvatskom pravu time je zbog različitog stvarno-pravnog uređenja hrvatskoga i austrijskog prava različit od položaja prekarista prema OGZ-u. Naime, prekarist je u austrijskom

60 Slobodan Perović, Obligaciono pravo (Beograd: Službeni list SFRJ, 1976.), 501; Bogdan Loza, Obligaciono pravo, Opšti dio (Sarajevo: Dom Štampe, 1978.), 119.

61 Čl. 515. st. 3. ZOO.

62 Vizner smatra kako prekarist na primljenoj stvari ima pravo uporabe te je kao takav detentor stvari i posjednik prava uporabe stvari. Boris Vizner, Građansko pravo: [u teoriji i praksi] (Rijeka: Štampa, 1962.), 653. Slično i u starijim izvorima, Ivan Ćepulić, Sistem općeg privatnog prava (Zagreb: Tipografija 1925.), § 273.

63 Čl. 10. st. 3. Zakona o vlasništvu i drugim stvarnim pravima. Zakon o vlasništvu i drugim stvarnim pravima, Narodne novine, br. 91/96., 68/98., 137/99., 22/00., 73/00., 129/00., 114/01., 79/06., 141/06., 146/08., 38/09., 153/09., 143/12., 152/14. (dalje u tekstu: ZV). Više o neposrednom posjedu stvari vidjeti: Nikola Gavella, et al., Stvarno pravo, svezak 1., 2. izmijenjeno i dopunjeno izd. (Zagreb: Narodne novine, 2007.), 166.

64 Petar Radošević, ,,Posjedovna volja“, Zbornik Pravnog fakulteta Sveučilišta u Rijeci 29, br. 2 (2008): 1135.

65 Čl. 18. ZV-a. 
pravu, isto kao i posudovnik samo imatelj, tj. detentor stvari. Kao takav, prekarist ima pravo na posjedovnu zaštitu u odnosu prema trećim osobama, no ne i protiv davatelja stvari u prekarij. ${ }^{66}$ Prema hrvatskom stvarno-pravnom uređenju prekarist je ovlašten štititi svoj posjed u sudskom postupku pokrenutom zbog smetanja posjeda ili samopomoći. ${ }^{67}$ Teško je zamisliti situaciju u kojoj bi prekarist imao pravo štititi svoj posjed od osobe koja mu je predala stvar u prekarij budući da ju je davatelj stvari mogao vratiti opozivom u bilo kojem trenutku. No, takva zaštita nije isključena ZVom. Naime, prekarist bi hipotetski imao pravo kao posredni posjednik stvari štititi svoj posjed i od davatelja stvari u prekarij, no u tom je pravu uvelike ograničen. ${ }^{68}$ To je pravo prekarista kao neposrednog posjednika isključeno u svim onim slučajevima u kojima bi se zahtjev za pružanje zaštite posjeda temeljio na utvrđivanju njihova međusobnog pravnog odnosa. ${ }^{69}$ Kako je nezamislivo pravo prekariste da posjeduje stvar bez utvrđivanja obvezno-pravnog odnosa kojim mu je predana na uporabu, navedena zakonska odredba u ovom slučaju je znatno ograničavajuća za ostvarivanje takve zaštite prekarista. ${ }^{70}$

Prekarist uživa zaštitu od smetanja trećih osoba pri izvršavanju uporabe stvari. Mora se napomenuti da se smetanjem izvršavanja uporabe stvari smatraju i čini smetanja trećih osoba usmjerenim protiv posrednog posjednika, a koji se negativno odražavaju na položaj prekariste kao neposrednog posjednika. Primjerice, oduzme li treća osoba stvar prekaristi, ona ju je oduzela i iz posrednog posjeda njezina davatelja, a pritom i iz svih posrednih posjeda koji su izgrađeni posredstvom tog posjeda. ${ }^{71}$ Tada i prekarist kao neposredni posjednik ostvaruje pravo na zaštitu neposrednog posjeda. Prekarist, nadalje, gubi pravo zahtijevati posjedovnu zaštitu ako ne udovolji zahtjevu za vraćanje stvari. Njegov posjed od trenutka oglušivanja o zahtjev davatelja stvari gubi obilježja zakonitog, istinitog i poštenog posjeda te postaje neistiniti, tj. viciozni posjednik jer je samovoljno, tj. zloupotrebom povjerenja (lat. precario modo)

66 Vidi više: § 313. ABGB-a. Schwimann, ABGB-Praxiskommentar, Bd. 4., §§ 859-1089, ABGB $\S 974,5-7 \S 974$.

67 Vidi: $\breve{C}$ l. 21. st. 4. ZV-a.

$68 \mathrm{U}$ odredbi čl. 163. st. 1. ZV-a definirano je pravo posjednika odbiti predaju stvari njezinom vlasniku ako ima pravo koje ga ovlašćuje na posjedovanje te stvari. S tim u vezi, kada je riječ o prekarnom posjedu, u judikaturi je izraženo stajalište: Kada vlasnik preda nekretninu u posjed drugoj osobi da je koristi, ne određujući točan rok uporabe, tada je ovlašten u svako doba opozvati takvo odobrenje za upotrebu. Takav opoziv predstavlja i podnošenje tužbe radi predaje u posjed, nakon čega posjednik nekretnine koristi nekretninu bez pravne osnove. VSRH Rev. 1/1992. od 04. 03. 1992., Izbor odluka VSRH iz 1993., sentenca br. 12. Olga Jeličić, Tužbe radi zaštite prava vlasništva, pristup 11. studenog, 2019., https://www. google.com/url? sa $=\mathrm{t} \& \mathrm{rct}=\mathrm{j} \& \mathrm{q}=\& \mathrm{esrc}=\mathrm{s} \&$ source $=\mathrm{web} \& \mathrm{~cd}=2 \& \mathrm{ved}=2 \mathrm{ahUKEwj}$ Thfzwq P1AhUrPewKHX1aAxEQFjABegQIAhAC\&url=http \% 3 A \% 2F\%2Fwww.vsrh. hr\%2FCustomPages\%2FStatic\%2FHRV\%2FFiles\%2FOJelcicTuzbe_radi_zastite_prava_ vlasnistva.doc\&usg=AOvVaw0TP22hkMPfo_Ao1_6zqoa5.

69 Jedan primjer iz sudske prakse kojim se isključuje pravo na posjedovnu zaštitu prekaristu ako je prekoračio granice neposrednog posjeda. VSH Gzz 36/84, 7.11.1984., pristup 21. studenog 2019., http://www.sodisce.si/znanje/sodna_praksa/pravna_mnenja_in_stalisca/31750/.

70 Vidi: Čl. 23. st. 2. ZV-a.

71 O samostalnom i nesamostalnom posjedu, kao i o posrednom i neposrednom posjedu vidjeti. Gavella et al., Stvarno pravo, 166, 170. 
davatelja stvari osamostalio svoj posjed. ${ }^{72}$

Sljedeće pitanje koje valja utvrditi jest po kojim bi pravilima davatelj stvari u prekarij u slučaju samovlasnog oduzimanja posjeda mogao postupati protiv prekariste. Naime, kako je prekarij obvezno-pravni ugovor, povreda ugovorne obveze čini se vjerojatnom tužbenom osnovom kojom bi davatelj stvari mogao ostvariti povrat posuđene stvari. Primjenom stvarno-pravnih pravila utvrđenih u ZV-u nije isključena mogućnost pokretanja vlasničke tužbe ${ }^{73}$ ni parnice zbog smetanja posjeda. ${ }^{74}$ No, time bi se u pogledu predmeta dokazivanja pravni položaj davatelja stvari uvelike otežao, budući da bi u slučaju korištenja tih procesnih sredstava morao zadovoljiti i druge preduvjete takve procesne zaštite. Utoliko, vlasnička tužba, prava ili predmnijevana, neće biti najprimjerenije sredstvo za vraćanje posuđene stvari onog davatelja koji nije ujedno i njezin vlasnik. ${ }^{75}$

S druge strane, posjedovna tužba koja podrazumijeva dokazivanje posljednjeg posjeda i čina uznemiravanja također bi posuditelju stavila puno veći zahtjev u pogledu tereta dokazivanja od tužbe utemeljene na povredi obvezno-pravnog odnosa. ${ }^{76}$ Svaki razborit posuditelj stvari radije će, stoga, utemeljiti svoj zahtjev na povredi obveznog odnosa, a od posudovnika prekarista, sada nepoštenog posjednika stvari, zahtijevati ne samo njezino vraćanje već i naknadu sve štete koje su na posuđenoj stvari nastale i sve koristi koje je imao tijekom svojega posjedovanja, pa i one koje bi stvar dala da ih nije zanemario. ${ }^{77}$

\section{ZAKLJUČAK}

Može se zaključiti kako sadržaj dostupnih izvora iz razdoblja kasnoga srednjeg vijeka nedvojbeno isključuje regulaciju instituta izmoljene posudbe, tj. prekarija, kada je riječ o hrvatskom pravnom području. To ne iznenađuje osobito ako se uzme u obzir da su se učinci toga pravnog posla bez sumnje mogli ostvariti institutom posudbe koja

72 Više o mirnom posjedu: Gavella et al., Stvarno pravo, 236. O smetanju posjeda učinjenom od strane prekarista str. 239.

73 Vidi više o pravnoj zaštiti vlasnika i posjednika: Nikola Gavella et al., Stvarno pravo (Zagreb: Narodne novine, 1998.), 453; Petar Klarić i Martin Vedriš, Građansko pravo (Zagreb: Narodne novine, 2014.), 294-296.

74 Čl. 22. st. 2. ZV-a. Više o zaštiti posjeda vidi u: Nikola Gavella, „O posjedu s obzirom na uređenje koje je uspostavio Zakon o osnovnim vlasničkopravnim odnosima“, Naša zakonitost XXXV, br. 4 (1981): 51- 64; Nikola Gavella, „O posjednikovoj volji, obzirom na uređenje posjedovanja zasnovano na objektivnoj koncepciji posjeda“, Zbornik Pravnog fakulteta Sveučilišta u Rijeci 4, (1983): 131- 143; Mladen Pavlović, „Sudska zaštita posjeda “, Hrvatska pravna revija, 3, br. (2003): 97-109; Tomislav Aralica, Smetanje posjeda u sudskoj praksi, Informator, 62 (2014): 6273-6274; Miljenko Giunio, „Zaštita posjeda - potreba ujednačenja prakse“, Pravo u gospodarstvu: časopis za gospodarsko-pravnu teoriju i praksu 53, br. 1 (2014): 153-158; Vladimir Flegar, „Posjed i njegova zaštita“, Zakonitost, br. 9-10 (1990): 1135.

75 Vidi više u sadržaju izvora navedenog u bilješci 71.

76 Vidi više u brojnoj literaturi navedenoj u bilješci 71.

77 Čl. 165. st. 1. ZV-a: Nepošteni posjednik tuđe stvari mora je predati vlasniku ili osobi koju taj odredi te naknaditi sve štete koje su na njoj nastale i sve koristi koje je imao za vrijeme svojega posjedovanja, pa i one koje bi stvar dala da ih nije zanemario. 
je, kao zaseban institut u većini izvora relativno kasno uvrštena. Hrvatsko-ugarsko pravo početkom 19. stoljeća ipak, po uzoru na austrijsku pravnu teoriju prepoznalo je ovaj institut kao zaseban pravni posao.

Pravila koja uređuju posudbu na hrvatskom području još od sredine 19. stoljeća preuzeta su iz austrijskog OGZ-a. Iako je tijek povijesnih i političkih prilika tijekom duljeg razdoblja od stotinu godina utjecao na nestabilnost i neujednačenost pravnog sustava, zahvaljujući dugogodišnjoj tradiciji primjene austrijskog prava na hrvatskom području regulacija OGZ-a, sve do 2005. pružala je primjereni pravni okvir za regulaciju pravnog instituta posudbe (time i izmoljene posudbe, tj. prekarija), koja, iznenađujuće nije uređena Zakonom o obveznim odnosima iz 1978. Pravna praznina na području instituta posudbe morala je biti popunjena zasebnom regulacijom navedenog instituta radi usklađivanja zakonskoga teksta s europskom pravnom stečevinom.

Regulacija instituta izmoljene posudbe u hrvatskom pravu gotovo je u potpunosti primjena odredaba austrijskoga OGZ-a u kojem je istoimeni institut definiran kao podvrsta ugovora o posudbi. Pravni položaj prekariste i posudovnika izjednačen je i usklađen s odredbama stvarnog prava prema kojem se tumače kao neposredni posjednici stvari. U tom pogledu pravni položaj posudovnika i posudovnika prekariste drukčiji je negoli u austrijskom pravu koje posudovnike, a time i prekariste, smatra pukim detentorima. Kako je ZV priznao pravo ostvarivanja posjedovne zaštite prekariste kao posjednika i protiv davatelja stvari u prekarij, učinilo se kako prekarij gubi svoju praktičnu svrhu. No, navedeno je poimanje prava na posjedovnu zaštitu ograničeno u čl. 23. st. 2. ZV-a te je time afirmiran jednak položaj prekariste, kao i u austrijskom pravu, a time i očuvana temeljna funkcija toga pravnog instituta.

\section{LITERATURA}

1. Apathy Peter, i Riedler, Andreas. Bürgerliches Recht, Bd. 3. Schuldrecht Besonderer Teil. Wien - New York: Springer-Verlag, 2010.

2. Aralica, Tomislav. "Smetanje posjeda u sudskoj praksi", Informator, 62 (2014): 62736274.

3. Barta, Heinz. Zivilrecht: Grundriss und Einführung in das Rechtsdenken, 2. Wien: WUVUniv.-Verlag, 2004.

4. Beuc, Ivan. Povijest država i prava na području SFRJ. Zagreb: Narodne novine, 1989.

5. Bogdan, Loza. Obligaciono pravo, Opšti dio. Sarajevo: Dom Štampe, 1978.

6. Crnić, Ivica. Zakon o obveznim odnosima: opsežna sudska praksa, napomene i komentari, detaljno abecedno kazalo pojmova. 6. izmijenjeno i dopunjeno izd. Zagreb: Organizator, 2016.

7. Ćepulić, Ivan. Sistem općeg privatnog prava. Zagreb: Tipografija, 1925.

8. Čepulo, Dalibor. Statut Paške općine. Statuta Communitatis Pagi. Pag. Zagreb: Ogranak Matice Hrvatske u Pagu - Pravni fakultet Sveučilišta u Zagrebu, 2011.

9. Đurović Radomir i Momir Dragašević. Obligaciono pravo: sa poslovima prometa. Beograd: Savremena administracija, 1980.

10. Eisner, Bertold i Mladen Pliverić. Mišljenja o Predosnovi građanskog zakonika za Kraljevinu Jugoslaviju, pravničko društvo u Zagrebu. Zagreb: Pravničko društvo u Zagrebu, 1937.

11. Flegar, Vladimir. "Posjed i njegova zaštita”. Zakonitost, 9-10 (1990): 1134-1149. 
12. Gavella, Nikola, „O posjednikovoj volji, obzirom na uređenje posjedovanja zasnovano na objektivnoj koncepciji posjeda“. Zbornik Pravnog fakulteta Sveučilišta u Rijeci 4, (1983): 131- 143.

13. Gavella, Nikola, "O posjedu s obzirom na uređenje koje je uspostavio Zakon o osnovnim vlasničkopravnim odnosima". Naša zakonitost XXXV, br. 4 (1981): 51- 64.

14. Gavella, Nikola, Mira Alinčić, Petar Klarić, Krešimir Sajko, Tanja Tumbri, Zlatan Stipković, Tatjana Josipović i Igor Gliha. Hrvatsko građanskopravno uređenje $i$ kontinentalnoeuropski pravni krug, Hrvatsko građanskopravno uređenje $i$ kontinentalnoeuropski pravni krug. Zagreb: Pravni fakultet u Zagrebu, 1994.

15. Gavella, Nikola, Tatjana Josipović, Igor Gliha, Vlado Belaj i Zlatan Stipković. Stvarno pravo, Svezak 1. 2. izmijenjeno i dopunjeno izd. Zagreb: Narodne novine, 2007.

16. Gavella, Nikola, Tatjana Josipović, Igor Gliha, Vlado Belaj i Zlatan Stipković. Stvarno pravo, Zagreb: Narodne novine, 2007.

17. Giunio, Miljenko. “Zaštita posjeda - potreba ujednačenja prakse”. Pravo u gospodarstvu: časopis za gospodarsko-pravnu teoriju i praksu 53 (2014): 153 -159.

18. Gorenc, Vilim, Hrvoje Kačer, Hrvoje Momčinović, Zvonimir Slakoper, Branko Vukmir i Loris Belanić. Obvezno pravo, Posebni dio 1., Pojedini ugovori. Zagreb: Novi informator, 2012.

19. Gross, Mirjana. Počeci moderne Hrvatske. Zagreb: Globus, Centar za povijesne znanosti Sveučilišta u Zagrebu, 1985.

20. Gschnitzer, Franz. Sachenrecht. Berlin Heidelberg: Springer-Verlag, 1968.

21. Jung, Johann von. Darstellung des Ungarischen Privat-Rechtes. Nach dem Werken: Institutiones Juris privati Hungarici, Emerich von Kelemen. Bd. 2. Wien: Beck, 1827.

22. Kelemen, Imre. Institutiones iuris Hungarici 2., Budae: Budae Univ. Hungaricae, 1818.

23. Klang, Heinrich Adalbert. Kommentar zum Allgemeinen Burgerlichen Gessetzbuch, Bd. 2., Halbd. 2. $\$ \oint 859 b i s$ 1089. Bearbeitet von Ernst Bettelheim, Franz Bschnitzer, Alfred Handl, Oskar Pisto, Wilhelm Schletzinger, Ernst Swoboda. Wien: Staatsdruckerei, 1934.

24. Klarić, Petar i Martin Vedriš. Građansko pravo. Zagreb: Narodne novine, 2014.

25. Konstantinović, Mihailo. Obligacije i ugovori: Skica za zakonik o obligacijama $i$ ugovorima. Beograd: Izdanje Centra za dokumentaciju i publikacije Pravnog fakulteta, 1969.

26. Koziol, Helmut i Rudolf Wesler. Grundiss des Bürgerlichen Rechts, Bd. 2. 13. Aufl. Wien: MANZ Verlag Wien, 2007.

27. Krasnopolski, Horaz. Osterreichisches Privatrecht, $B d . \quad 3 .:$ Österreichisches Obligationenrecht. Aus dessen Nachlaß hrsg. und bearb. von Bruno Kafka. Mit einem Geleitwort von Ludwig Mitteis., Mitarbeit: Mitteis, Ludwig; Herausgegeben von Kafka, Bruno. Berlin: Verlag: Duncker \& Humblot, 2013.

28. Lanović, Mihajlo. Privatno pravo Tripartita. Zagreb: Tisak Tipografija, 1929.

29. Margetić, Lujo. Krčki (Vrbanski) statut iz 1388. Krk: Povijesno društvo Saveza povijesnih društava Hrvatske, 1988.

30. Margetić, Lujo. Osnove obveznog prava na kvarnerskom području u srednjem vijeku. Zagreb: Jugoslavenska akademija znanosti i umjetnosti, 1989.

31. Margetić, Lujo. Srednjovjekovno hrvatsko pravo. Obvezno pravo. Zagreb, Rijeka: HAZU, 1997.

32. Margetić, Lujo i Petar Strčić. Statut rapske komune iz 14. stoljeća = [Statut communis Arbae], Rab-Rijeka: Adamić, 2004.

33. Margetić, Lujo, Ivan Beuc i Dalibor Čepulo. Hrvatska pravna povijest u europskom kontekstu. Zagreb: Pravni fakultet u Zagrebu, 2005.

34. Maurović, Ivan. Izvještaj o predosnovi gradjanskog zakonika za kraljevinu Jugoslaviju. Zagreb: T. Knjižare St. Kugli, 1934.

35. Maurović, Ivan. Nastojanja i Pokušaji da se reformira Opći građanski zakonik, Kratak pregled s nekoliko kritičkih napomena. Zagreb: Jugoslavenska akademija, 1940. 
36. Pavlović, Mladen. „Sudska zaštita posjeda”. Hrvatska pravna revija 33, 3 (2003): 97-109.

37. Pera, Miroslav. Poljički statut. Split: Književni krug Split, 1988.

38. Perović, Slobodan. Obligaciono pravo. Beograd: Službeni list SFRJ, 1976.

39. Perović, Slobodan. „Stručno mišljenje o Nacrtu Zakona o obligacionim odnosima Republike Srpske/Federacije BiH (Knj. I., Opšti deo, sa stanjem 28. I. 2003)“. Anali Pravnog fakulteta u Beogradu, vol. 51, br. 1-2, (2003): 10-86.

40. Petrak, Marko. „Rimska pravna tradicija i hrvatsko stvarno pravo“. Zbornik Pravnog fakulteta u Zagrebu 52, br. 2 (2002): 71-83.

41. Putz, Karl. System des ungarischen Privatrechts. Wien: Verlag der G.J. Manz'schen Buchhandlung, 1870.

42. Radošević, Petar. „Posjedovna volja“. Zbornik Pravnog fakulteta Sveučilišta u Rijeci 29, br. 2 (2008): 1129- 1147.

43. Radovčić, Vesna. Pokušaj kodifikacije građanskog prava u Staroj Jugoslaviji: predosnova Građanskog zakonika za Kraljevinu Jugoslaviju. Zagreb: Institut za hrvatsku povijest, 1975.

44. Reßler, Roman, „Voraussetzungen der Unentgeltlichkeit bei prekaristischer Überlassung einer Wohnung für Wohnzwecke nach § 974 ABGB“. Pristup 30. rujna 2019. https://www. weka.at/wohnrecht/News/Voraussetzungen-der-Unentgeltlichkeit-bei-prekaristischerUeberlassung-einer-Wohnung-fuer-Wohnzwecke-nach-974-ABGB?print=1

45. Riedler, A. Zivilrecht III, Schuldrecht, Besonderer Teil: Vertragliche Schuldverhaltnisse, 4. Aufl. Wien: LexisNexis, 2015.

46. Riss, Petar Garai, „Zur Abgrenzung von Leihe und Miete (Anerkennungszings)“. Wohnrechtliche Blätter. 22, br. 4 (2009): 129-132.

47. Rummel, Peter. Komentar zum Allgeimenen buerglichen Gesetzbuch 1 \&\$ 1 bis 1089 $A B G B$. Wien: Verlag, MANZ Verlag Wien, 1983.

48. Schey, von, Josef. Die Obligationsverhältnisse des österreichischen allgemeinen Privatrechtsp., $B d$. 1. Wien: Manzsche k.u.k. Hof-Verlags- u. Universitäts-Buchhandlung, 1895.

49. Schuhmacher, Wolfgang i Gerwin Haybäck. Schuldverträge. Wien: LexisNexis, 2014.

50. Schwimann, Michael. ABGB-Praxiskommentar. Bd. 4., §§ 859-1089 ABGB. 3. neue bearbeitete Aufl. Wien: LexisNexis, 2006.

51. Statut grada Splita, srednjovjekovno pravo Splita. 2. izd. Split: Književni krug, 1987.

52. Stein, Peter. Rimsko pravo i Europa - Povijest jedne pravne culture. Zagreb: Golden marketing - Tehnička knjiga, 2007.

53. Stubenrauch, Moriz von, Maximilian Schuster von Bonnott; Alfred von Seiller i Moriz von Stubenrauch. Österreich., Commentar zum österreichischen Allgemeinen bürgerlichen Gesetzbuche. 8. Aufl., Wien: 1903.

54. Svoboda, Milan (preveo, preradio i dopunio). Privatno pravo u Vojvodini i Medjimurju (mađarsko privatno pravo) usporedjeno sa sistemom austr. O.g.z. s Originala Slovačko privatno pravo od Dr. Josipa Singera. Zagreb: Tiskom Jugoslavenskog Novinskog (Ivan Malinar), 1926.

55. Van den Berg, Peter A. J. The Politics of European Codification. Groningen-Amsterdam: Europa Law Publishing, 2007.

56. Von Randa, Anton. Der Besitz nach österreichischem Rechte mit Berücksichtigung des gemeinen Rechtes, des preussischen, französischen und italienischen, des sächsischen und züricherischen Gesetzbuches. Leipzig: Breitkopf und Härtel, 1895.

57. Vuković, Mihajlo. Opći građanski zakonik: s novelama i ostalim naknadnim propisima. Zagreb: Školska knjiga, 1955.

58. Wesler, Rudolf. Grundriss des burgerlichen Rechts, Bd. 2. Schuldrecht Allgemeiner Teil, 13. nubearbeitete Aufl. Wien: Mansche Verlags und Universitatsbuchhandlung, 2007.

59. Wieger, Daniela. Besitzstörung, Praxisleitfaden mit vielen Beispielen und Mustern. Wien: Linde Verlag Ges.m.b.H., 2016. 
60. Winiwarter, Joseph Max von. Das persönliche Sachenrecht nach dem Oesterreichischen allgemeinen bürgerl. Gesetzbuche: Systematisch dargestellt und erläutert. 2. verm. und verb. Aufl. Wien: Braumüller und Seidel, 1837.

61. Zakon o obveznim odnosima, Narodne novine, br. 35/05., 41/08., 125/11., 78/15., 29/18.

62. Zakon o vlasništvu i drugim stvarnim pravima, Narodne novine, br. 91/96., 68/98., 137/99., 22/00., 73/00., 129/00., 114/01., 79/06., 141/06., 146/08., 38/09., 153/09., 143/12., 152/14. 


\author{
Jelena Kasap* \\ Višnja Lachner**
}

Summary

\title{
LEGAL-HISTORICAL OVERVIEW OF THE DEVELOPMENT OF THE INSTITUTE OF PRECARIOUS LOAN IN CROATIAN LEGISLATION
}

The two legal institutes, the precarium, i.e. precarious loan and loan for use are often identified in everyday speech even in the legal context, and revocability is emphasized as the only feature of their differentiation. Taking into account the opinion of legal theorists according to which the legal effect of the precarium can be achieved by applying the rules on borrowing, some of the modern codifications of civil law failed to define the precarious loan as an independent legal institute. Nevertheless, the Croatian legislator, guided by the historical application of the Austrian General Civil Code in the Croatian territory, standardized the institute of the precarious loan by a separate legal provision and thus defined it by the subtype of the contract of loan for use.

The very rare use of this institute in legal practice as well as the lack of interest for this institute in modern civil law theory make the nature of this institute still insufficiently clear. A comparative analysis of legal theory, but also of foreign legislation that served as a basis for drafting the legal framework of borrowing in Croatian law will try to determine the features of the precarious loan and point to cases where the application of this institute is particularly opportune. Despite the similarity of the two mentioned legal institutes of loan for use and the precarious loan that will be pointed out in the content, the basic purpose of this research is to emphasize the importance of each institute taking into account the features that distinguish them and confirm that both institutes have their own purpose, practical importance and application in Croatian law.

Keywords: precarium; loan for use; revocation; General Civil Code.

* Jelena Kasap, Ph.D., Assistant Professor, Faculty of Law, Josip Juraj Strossmayer University of Osijek; jkasap@pravos.hr.

** Višnja Lachner, Ph.D., Assistant Professor, Faculty of Law, Josip Juraj Strossmayer University of Osijek; vlachner@pravos.hr. 


\section{Zusammenfassung}

\section{RECHTSGESCHICHTLICHER ÜBERBLICK VON DER NORMUNGSENTWICKLUNG DES BITTLEIHENS IM KROATISCHEN RECHT}

Oft werden die schuldrechtlichen Institute Bittleihen, bzw. Precarium und Leihe in der Alltagssprache aber auch im rechtlichen Kontext gleichgestellt, wobei Rückforderung als einzelner Unterscheidungspunkt hervorgehoben wird. Trotz Meinung von Rechtstheoretikern, dass die Rechtswirkung des Bittleihens durch Anwendung der Leihvorschriften geltend gemacht werden kann, haben einige der zeitgenössischen Kodifikationen des bürgerlichen Rechts versäumt, das Bittleihen als eigenständiges Rechtsinstitut $\mathrm{zu}$ regeln. Ungeachtet dessen habe der kroatische Gesetzgeber, geprägt vom ABGB, im kroatischen Gebiet das Bittleihen durch eine Gesetzesbestimmung als Norm überarbeitet und als Unterbegriff des Leihvertrags definiert.

Da in der Praxis selten auf Bittleihen zurückgegriffen wird, und, darüber hinaus, im Rahmen der modernen Theorie des bürgerlichen Rechts dafür kaum Interesse vorhanden ist, bestehen weiterhin viele Unklarheiten in Bezug auf dessen Geltung und Tragweite. Anhand einer vergleichenden Analyse der Rechtstheorie und ausländischer Gesetzgebung, die als Modell für den kroatischen gestezlichen Rahmen gedient hat, werden die Besonderheiten des Bittleihens und Fälle in denen die Anwendung dieses Instituts besonders opportun wäre, aufgezeigt. Trotz Ähnlichkeiten zwischen diesen Rechtsinstituten wird auf die Bedeutung eines jeden Rechtsinstituts hingewiesen. In Anbetracht der Untescheidungspunkte der Institute wird schlussgefolgert, dass beide besondere Zwecke bewirken, sowie praktische Geltung und Tragweite im kroatischen Recht erfahren haben.

Schlüsselwörter: Precarium; Bittleihen; Leihe; Rückforderung; ABGB.

Riassunto

\section{RASSEGNA STORICO-GIURIDICA DELLO SVILUPPO DELLA DISCIPLINA DELL'ISTITUTO DEL PRECARIUM NEL DIRITTO CROATO}

Spesso nel linguaggio quotidiano, persino nel contesto giuridico, si equiparano due istituti giuridici del diritto delle obbligazioni, e cioè il precarium ed il prestito, ponendo l'accento sulla revocabilità quale circostanza per la loro delimitazione. Tenendo conto dell'orientamento teorico secondo il quale gli effetti giuridici del precarium possono trovare realizzazione applicando le regole sul prestito, alcune 
codificazioni moderne del diritto civile hanno tralasciato di disciplinare il precarium come istituto giuridico autonomo. Comunque, il legislatore croato, guidato dall'applicazione storica del Codice civile generale austriaco sul territorio croato ha normato tale istituto con una disposizione di legge speciale ed in questo modo lo ha definito come una sottospecie del contratto di prestito.

L'uso molto raro di questo istituto nella giurisprudenza proprio come l'assenza di interesse per la natura giuridica del precarium nella teoria moderna del diritto civile fa sembrare la natura di questo istituto ancora poco chiara. Con l'analisi comparata della teoria giuridica, ma anche della legislazione straniera, che ha fatto da base per la creazione del quadro normativo del prestito nel diritto croato, si tenterà di determinare le particolarità del precarium e di far luce sulle situazioni nelle quali l'applicazione di questo istituto è particolarmente opportuna. A parte le somiglianze dei due negozi giuridici menzionati, e cioè del prestito e del precarium di cui si parlerà nel testo, l'obiettivo di base di questa ricerca è mettere in evidenza l'importanza di ogni singolo istituto prendendo in considerazione le particolarità che li delimitano, rilevando come entrambi gli istituti abbiano i loro obiettivi, l'importanza pratica e l'esperienza dell'esistenza nel diritto croato.

Parole chiave: precarium; prestito; revocabilità; Codice civile generale. 
